Jana Filipič, Dominika Glažar, Špela Jerebic, Daša Kenda, Anja Modic, Barbara Roškar, Iris Vrhovski, Danaja Štular, Barbara Golja, Samo Smolej, Brigita Tomšič, Marija Gorjanc, Barbara Simončič University of Ljubljana, Faculty of Natural Sciences and Engineering, Aškerčeva 12, 1000 Ljubljana, Slovenia

\title{
Tailoring of Antibacterial and UV-protective Cotton Fabric by an in situ Synthesis of Silver Particles in the Presence of a Sol-gel Matrix and Sumac Leaf Extract
} Izdelava protibakterijske in UV zaščitne bombažne tkanine z in situ sintezo srebrovih delcev $v$ prisotnosti sol-gel matrice in ekstrakta listov octovca

\author{
Original scientific article/lzvirni znanstveni članek \\ Received/Prispelo 10-2018 • Accepted/Sprejeto 12-2019
}

\begin{abstract}
This research presents a new procedure for the chemical modification of cotton fabric, which included a "green" in situ synthesis of silver particles using an extract of sumac leaves as a reducing agent. To increase the adsorption ability of silver cations, a sol-gel matrix was previously created on cotton fabric using an organic-inorganic precursor sol-gel. The presence of silver particles on the cotton fabric was confirmed by scanning electron microscopy and energy-dispersive X-ray spectroscopy. The results showed that silver particles were created on the cotton fabric in the presence of the sumac leaf extract, which colored the fibers in brown. The presence of the sol-gel matrix increased the adsorption of silver cations and therefore the concentration of sliver particles, which resulted in a deeper color yield. Silver particles provided antibacterial protection, with a 99-100\% reduction of E. coli in S. aureus bacteria, while the sumac leaf extract provided excellent protection against ultraviolet radiation, with an ultraviolet protective factor equaling 66.54 . The coating was also highly durable in terms of its washing fastness.

Keywords: silver particles, in situ synthesis, sumac leaves, cotton, sol-gel matrix, antibacterial activity, UV-protection
\end{abstract}

Izvleček

$\checkmark$ raziskavi je predstavljen nov postopek kemijske modifikacije bombažne tkanine, ki vključuje »zeleno« in situ sintezo srebrovih delcev z uporabo ekstrakta listov octovca kot reducenta. Za povečanje stopnje adsorpcije srebrovih kationov je bila na bombažni tkanini predhodno oblikovana sol-gel matrica z uporabo reaktivnega organskegaanorganskega hibridnega prekurzorja. Vzorci bombažne tkanine so bili potopljeni v raztopno $\mathrm{AgNO}_{3}$ pri ustreznih pogojih, v njo pa je bil naknadno dodan ekstrakt octovca. Po obdelavi je bila tkanina večkrat prana. Prisotnost srebrovih delcev na bombažni tkanini je bila potrjena z vrstično elektronsko mikroskopijo z energijsko-disperzijsko spektroskopijo rentgenskih žarkov. I r rezultatov raziskave je razvidno, da so se v prisotnosti ekstrakta listov octovca na bombažni tkanini oblikovali srebrovi delci, ki so vlakna obarvali v rjavem barvnem tonu. Prisotnost sol-gel matrice je povečala adsorpcijo srebrovih kationov ter stem koncentracijo srebrovih delcev, kar se je odrazilo v temnejšem barvnem tonu. Srebrovi delci so podelili tkanini protibakterijsko zaščito z 99-100-odstotno redukcijo bakterij E. coli in S. aureus, prisotnost ekstrakta listov octovca pa je nudila odlično zaščito pred ultravijoličnim sevanjem z ultravijoličnim zaščitnim faktorjem enakim 66,54. Apretura je bila visoko pralno obstojna.

Ključne besede: srebrovi delci, in situ sinteza, listi octovca, bombaž, sol-gel matrica, protimikrobna aktivnost, UV zaščita 


\section{Introduction}

In textiles, silver particles (Ag Ps) have been recognized as effective antimicrobial agents, with broadspectrum activity against bacteria, fungi and viruses. Besides zinc oxide and titanium dioxide, Ag Ps are mostly used for the fabrication of medical and hygiene textiles. However, the antimicrobial mechanism of Ag Ps is not yet fully known, yet the activity has been attributed to silver cations $\left(\mathrm{Ag}^{+}\right)$, which are released from the surface of Ag Ps, and to Ag Ps, if their size is within a nanometer scale (Ag NPs) $[1,2]$. Both $\mathrm{Ag}^{+}$and $\mathrm{Ag}$ NPs can interact with the bacterial cell wall, where their accumulation causes membrane damage. Furthermore, $\mathrm{Ag}^{+}$and Ag NPs lower than $10 \mathrm{~nm}$ can penetrate the cell, where they hinder or deactivate its critical physiological functions and consequently destroy the cell. In the presence of oxygen, $\mathrm{Ag}^{+}$and $\mathrm{Ag}$ NPs may also catalytically accelerate the formation of reactive oxygen species (ROS), which are highly toxic to microorganism cells $[1,2]$.

There are several classical and contemporary approaches for the application of Ag Ps to textile substrates, which include the application of pre-synthesized Ag Ps using an appropriate finishing method or an in situ synthesis of Ag Ps in the presence of a textile substrate [3-5]. An important advantage of the in situ generation of $\mathrm{Ag} \mathrm{Ps}$ is that it enables the growth of Ag Ps inside the textile fibers, increases the homogeneity and uniformity of the particle distribution inside and on the fiber surface, and reduces the agglomeration of particles. In this process, no additional methods or chemicals are needed to enhance dispersibility of the ex situ synthesized Ag Ps and to achieve their stability against agglomeration. However, in both approaches, Ag Ps are formed in the chemical reduction of silver salt, where different environmentally harmful organic or inorganic reducing and stabilizing agents are usually used. To avoid toxic chemicals and perform the fabrication processes more sustainably, biological methods for the synthesis of Ag Ps, in which extracts of plants and microorganisms are used as reducing and stabilizing agents, have received increasing attention [6-8].

The in situ biosynthesis of Ag Ps represents a 'green' fabrication process of $\mathrm{Ag}$-functionalized textile substrates. In this process, $\mathrm{AgNO}_{3}$, as a silver precursor, and plant extracts, as reducing and stabilizing agents, have mostly been used simultaneously.
Namely, natural biomolecules with carbonyl and phenolic hydroxyl functional groups, including alkaloids, tannins, flavonoids, phenols, amino acids, and polysaccharides, have been extracted from leaves, seeds, peel, and fruits of different plants and introduced in the reduction of silver precursors to Ag Ps [9-17]. Among plant extracts, extracts from sumac (Rhus spp.) could be introduced as a promising reducing agent because of the variety of biological active compounds present in sumac's bark, branches, roots, leaves, seeds and fruits $[18,19]$. Sumac is native to the temperate regions of North America, but it has also been spread worldwide and developed as a sustainable non-traditional economic plant. While different parts of sumac have already been used in food and cosmetic industries, to the best of our knowledge, sumac has not yet been used for the production of the micro- and nanoparticles of metals or metal oxides.

Therefore, the aim of this research was to develop a novel process for the in situ synthesis of Ag Ps on cotton fibers using sumac leaf extracts. To increase the adsorption ability of silver cations, an organicinorganic hybrid sol-gel precursor was applied to fibers to create a sol-gel matrix, prior the immersion of the fibers in $\mathrm{AgNO}_{3}$. Namely, we assumed that the presence of a sol-gel matrix on cotton fibers will increase their concentration of Ag Ps, as well as enhance their coating durability in comparison to fibers with no sol-gel matrix. The chemically modified cotton fibers were characterized by scanning electron microscopy (SEM) and energy-dispersive $\mathrm{X}$-ray spectroscopy (EDS). Their antibacterial properties were investigated against the Gram-positive Staphylococcus aureus and the Gram-negative Escherichia coli bacteria. Their ultraviolet (UV) protection properties were determined in terms of the ultraviolet protection factor (UPF). An important goal of the research was also to determine the washing fastness of the coating.

\section{Experimental \\ 2.1 Materials}

Alkaline-scoured, bleached, and mercerized 100\% cotton plain-weave fabric (Tekstina d.o.o., Ajdovščina, Slovenia), with a mass per unit area of $119 \mathrm{~g} / \mathrm{m}^{2}$, was used for chemical modification. To create a solgel matrix on the cotton fabric, iSys MTX (CHT R. 
Beitlich GmbH, Tübingen, Germany), a reactive organic-inorganic sol, which is miscible with water at every ratio, was used in combination with Kollasol $\mathrm{CDO}$, an anti-foaming agent (CHT R. Beitlich $\mathrm{GmbH}$, Tübingen, Germany). Silver nitrate $\left(\mathrm{AgNO}_{3} ; 99.98 \%\right.$, Sigma Aldrich) was used as a silver precursor. Fresh leaves of sumac were supplied by the public holding company, JP VOKA SNAGA d.o.o. All solutions were prepared in double-distilled water.

\subsection{Preparation of the sumac leaf extract solution}

First, $20 \mathrm{~g}$ of dried sumac leaves were crushed and poured with $1000 \mathrm{ml}$ of water. The mixture was heated to $98^{\circ} \mathrm{C}$ and let to boil for $20 \mathrm{~min}$ at a gentle boiling. Afterwards, the extract was filtered and cooled at room temperature.

\subsection{Chemical modification of the cotton fabric}

The modification of the cotton fabric samples was performed in a two-step procedure (Figure 1). Firstly, $15 \mathrm{~g} / \mathrm{l}$ iSys MTX in the combination with 1 $\mathrm{g} / \mathrm{l}$ Kollasol CDO were prepared in double-distilled water and applied to the cotton samples by a pad-dry-cure method, including full immersion at room temperature, a wet-pick-up of $80 \%$, drying at $100{ }^{\circ} \mathrm{C}$ and curing for $3 \mathrm{~min}$ at $150^{\circ} \mathrm{C}$. The concentrations of the agents and the application conditions were those recommended by the producer. After the treatment, the samples were left for seven days under standard atmospheric conditions $\left(65 \% \pm 2 \%\right.$ relative humidity and $\left.20^{\circ} \mathrm{C} \pm 1{ }^{\circ} \mathrm{C}\right)$ to allow for a complete sol-gel matrix formation. In the second step, the samples without and the samples with the sol-gel matrix were immersed in a $1.0 \times 10^{-3} \mathrm{M} \mathrm{AgNO}_{3}$ solution, at a liquor ratio of $1: 25$, and treated for $10 \mathrm{~min}$ at $60^{\circ} \mathrm{C}$ under constant stirring in a Girowash machine (James Heal, GB). Then, the sumac leaf extract solution was added, until the liquor ratio was 1:50, and the samples were treated in the solution for 60 min under the same conditions. For comparison, the fabric samples were treated with the sumac leaf extract solution, without the previous application of $\mathrm{AgNO}_{3}$. After the treatment, the samples were rinsed in cold distilled water, squeezed and dried at room temperature. The procedures of the chemical modifications of the fabric samples and the corresponding sample codes are summarized in Table 1.

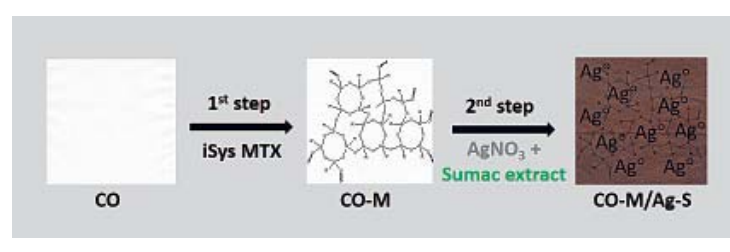

Figure 1: Schematic presentation of the procedure of cotton fabric chemical modification (Ag represents $\mathrm{Ag} P$ )

Table 1: Sample codes according to the chemical modification of the cotton fabric

\begin{tabular}{|l|l|}
\hline \multicolumn{1}{|c|}{$\begin{array}{c}\text { Sample } \\
\text { code }\end{array}$} & \multicolumn{1}{|c|}{$\begin{array}{c}\text { Description of chemical } \\
\text { modification }\end{array}$} \\
\hline $\mathrm{CO}$ & No modification \\
\hline $\mathrm{CO}-\mathrm{M}$ & $\begin{array}{l}\text { Application of iSys } \mathrm{MTX} \text { in } \\
\text { combination with Kollasol CDO }\end{array}$ \\
\hline $\mathrm{CO} / \mathrm{S}$ & $\begin{array}{l}\text { Treatment of } \mathrm{CO} \text { sample in sumac } \\
\text { leaves extract solution without prior } \\
\text { application of } \mathrm{AgNO}_{3}\end{array}$ \\
\hline $\mathrm{CO}-\mathrm{M} / \mathrm{S}$ & $\begin{array}{l}\text { Treatment of CO-M sample in } \\
\text { sumac leaves extract solution } \\
\text { without prior application of AgNO }\end{array}$ \\
\hline $\mathrm{CO} / \mathrm{Ag}-\mathrm{S}$ & $\begin{array}{l}\text { Application of } \mathrm{AgNO}_{3} \text { to the } \mathrm{CO} \\
\text { sample followed by the sample } \\
\text { treatment in sumac leaves extract } \\
\text { solution }\end{array}$ \\
\hline $\begin{array}{l}\mathrm{CO}-\mathrm{M} / \\
\mathrm{Ag}-\mathrm{S}\end{array}$ & $\begin{array}{l}\text { Application of } \mathrm{AgNO}_{3} \text { to the } \mathrm{CO}-\mathrm{M} \\
\text { sample followed by the sample } \\
\text { treatment in sumac leaves extract } \\
\text { solution }\end{array}$ \\
\hline
\end{tabular}

\subsection{Analyses and measurements}

\subsubsection{Scanning electron microscopy (SEM) and energy-dispersive $X$-ray spectroscopy (EDS)}

Untreated and chemically modified cotton fabric samples were analyzed using a field emission scanning electron microscope, FEG-SEM Thermo Scientific Quattro S (ThermoFischer Scientific, USA). The sample analysis was performed using an Oxford Instruments Ultim Max 65 Energy-dispersive Detector (EDS) and AZtec software. The samples were coated with a thin layer of carbon before observation to provide conductivity and hence the quality of the images.

\subsubsection{Antibacterial activity}

The bacterial reduction on the functionalized samples was evaluated against the Gram-positive Staphylococcus aureus (ATCC 6538) and the Gram-negative 
Escherichia coli (ATCC 25922) bacteria, according to the standard method, ASTM E 2149-01. The reduction in the number of bacteria, $R$, was calculated as follows [20]:

$R=\frac{(B-A)}{B} \times 100(\%)$

where $R$ is the bacterial reduction, $A$ is the number of bacteria colony forming units per $\mathrm{ml}(\mathrm{CFU} / \mathrm{ml})$ in a flask containing a chemically modified sample, after 1 hour of contact time, and $B$ is the number of bacteria colony forming units per $\mathrm{ml}(\mathrm{CFU} / \mathrm{ml})$ in a flask containing an unmodified reference sample, after 1 hour of contact time. Two parallel assessments with eight CFU counts were carried out for each functionalized sample and the $R$ value was reported as the mean value and the standard error.

\subsubsection{UV protection properties}

The UV protection properties of untreated and chemically modified cotton fabric samples, before and after repetitive washings, were determined according to the AATCC TM 183 standard. The measurements were performed using a Varian CARY 1E UV/Vis spectrophotometer (Varian, Australia), containing a DRA-CA-301 integration sphere and Solar Screen software. The transmission of the ultraviolet radiation through the samples were measured within the $280-400 \mathrm{~nm}$ spectral region, and the average transmittance $(T)$ at the wavelengths between 315 $\mathrm{nm}$ and $400 \mathrm{~nm}$ (UV-A), $280 \mathrm{~nm}$ and $315 \mathrm{~nm}$ (UV-B) and $280 \mathrm{~nm}$ and $400 \mathrm{~nm}$ (UV-R) were determined from the measurements. The ultraviolet protection factor $(U P F)$ was calculated as follows [21]:

$$
U P F=\frac{\sum_{\lambda=280}^{400} E_{\lambda} \times S_{\lambda} \times \Delta_{\lambda}}{\sum_{\lambda=290}^{400} E_{\lambda} \times S_{\lambda} \times T_{\lambda} \times \Delta \lambda}
$$

where $E_{\lambda}$ is the relative erythemal spectral effectiveness, $S_{\lambda}$ is the solar spectral irradiance, $T_{\lambda}$ is the spectral transmittance of the specimen, and $\Delta \lambda$ is the measured wavelength interval in $\mathrm{nm}$. The higher the UPF, the higher the protection. The UPF rating and UVR protection categories were determined from the calculated UPF values, according to the Australian/New Zealand Standard: Sun protective clothing - Evaluation and classification [22]. Additionally, the transmission of the samples was measured within the $280-800 \mathrm{~nm}$ spectral region with the use of the UV/Vis spectrophotometer Lambda 800 (Perkin Elmer, UK) equipped by the integrating sphere PELA-1000.

\subsubsection{Washing fastness}

The fabric samples were washed once $(1 \mathrm{~W})$ and 5 times $(5 \mathrm{~W})$ in a Girowash machine (James Heal, GB), according to the ISO 105-C06 standard method. The washing cycles were performed in a SDC standard detergent solution, at a concentration of $4 \mathrm{~g} / \mathrm{l}$, at $40{ }^{\circ} \mathrm{C}$ for $45 \mathrm{~min}$. After washing, the samples were rinsed in distilled water at $40{ }^{\circ} \mathrm{C}$ for $1 \mathrm{~min}$, subsequently rinsed in tap water, and then dried in air at room temperature.

\subsubsection{Colour measurements}

The CIELAB color coordinates of the untreated and chemically modified cotton samples, before and after repetitive washings and illumination, were determined using a Datacolor Spectraflash 600 PLUSCT spectrophotometer. The measurements were performed with a $30-\mathrm{mm}$ aperture under $\mathrm{D}_{65}$ illumination and an observation angle of $10^{\circ}$. The average of ten measurements was provided for each sample, and the color difference, $\Delta E^{\star}$, was calculated using the following equation [23]:

$\Delta E_{a b}^{*}=\sqrt{\left(\Delta L^{\star}\right)^{2}+\left(\Delta a^{\star}\right)^{2}+\left(\Delta b^{*}\right)^{2}}$

where $\Delta L^{*}, \Delta a^{*}$ and $\Delta b^{*}$ are differences between the color coordinates of the two samples.

\section{Results and discussion}

\subsection{Sample characterization}

The SEM/BSE images, shown in Figure 2, revealed numerous bright spots on the surface of the $\mathrm{CO} /$ $\mathrm{Ag}-\mathrm{S}$ and $\mathrm{CO}-\mathrm{M} / \mathrm{Ag}-\mathrm{S}$ samples, confirming that the presence of phenols, such as gallic acid, myricetin and quercetin derivatives, myricetin 3-rhamnoside, quercetin 3-glucoside as well as penta to decagalloyl-glucosides in the sumac leaf extract [18, 19, 24], successfully converted $\mathrm{Ag}^{+}$to $\mathrm{Ag}^{\circ}$ in the reduction reaction. The results also show that the application of a sol-gel matrix (CO-M sample) did not significantly change the fiber surface morphology, but it importantly influenced the adsorption ability of $\mathrm{Ag}^{+}$. A comparison of CO/Ag-S and CO-M/Ag-S clearly showed that the amount of Ag was significantly 

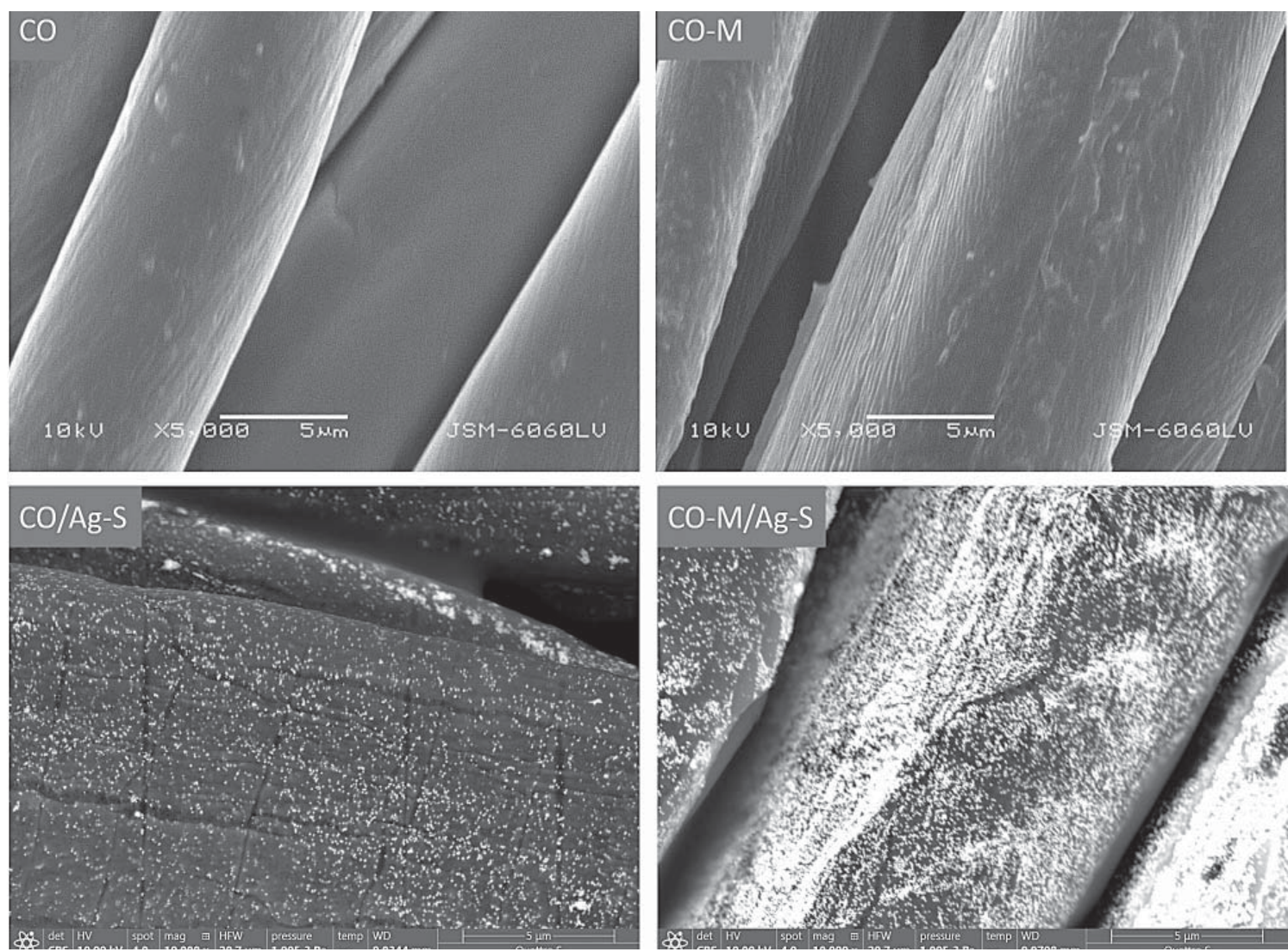

Figure 2: SEM/CBS images of CO, CO-M, CO/Ag-S and CO-M/Ag-S samples

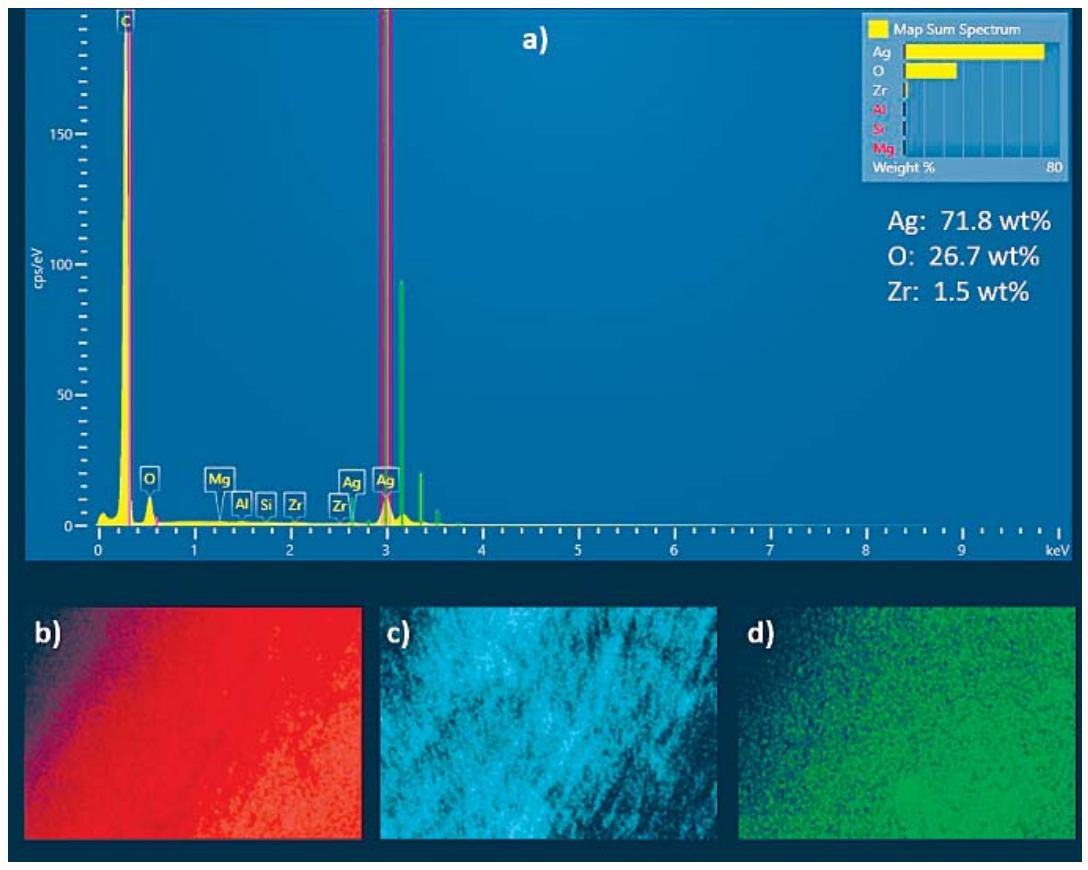

Figure 3: EDS spectrum acquired from $\mathrm{Ag}$ particles (a) and element mapping images of $C(b), A g(c)$ and $O(d)$ on the CO-M/Ag-S sample 
higher on the CO-M/Ag-S sample with the incorporated sol-gel matrix than on the $\mathrm{CO} / \mathrm{Ag}-\mathrm{S}$ sample without the sol-gel matrix.

The presence and distribution of the Ag element on the surface of the CO-M/Ag-S sample was confirmed by the EDS spectrum and element mapping images of $\mathrm{C}, \mathrm{Ag}$ and $\mathrm{O}$ (Figure 3). The EDS spectrum showed a strong characteristic peak, corresponding to $\mathrm{Ag}$ at $2.984 \mathrm{keV}$. Furthermore, the element mapping images suggested that $\mathrm{Ag}$ was rather homogeneously distributed on the fiber surface, along with the intrinsic elements, $\mathrm{C}$ and $\mathrm{O}$.

\subsection{Functional properties of the chemically modified samples}

The photo images of the untreated and chemically modified cotton fabric samples, shown in Figure 4, revealed that the application of the sol-gel matrix did not cause a visible color change in the cotton fibers, which generally remained white. In contrast, the treatment of cellulose fibers with sumac leaf extract colored the CO/S and CO-M/S samples in yellow (an increase in the positive value of the coordinate $b^{*}$ ), which was slightly more yellow, if the sol-gel matrix

\begin{tabular}{|c|c|}
\hline CO & CO-M \\
\hline $\begin{array}{l}L^{*}=94.46 \\
a^{*}=-0.16 \\
b^{*}=1.72\end{array}$ & $\begin{array}{l}L^{*}=95.38, \\
a^{*}=-0.32, \\
b^{*}=2.76\end{array}$ \\
\hline $\mathrm{co} / \mathrm{s}$ & CO-M/S \\
\hline $\begin{array}{l}L^{*}=85.91, \\
a^{*}=-0.38 \\
b^{*}=14.02\end{array}$ & $\begin{array}{l}L^{*}=83.09 \\
a^{*}=-0.20 \\
b^{*}=16.27\end{array}$ \\
\hline $\mathrm{CO} / \mathrm{Ag}-\mathrm{S}$ & $\mathrm{CO}-\mathrm{M} / \mathrm{Ag}-\mathrm{S}$ \\
\hline $\begin{array}{l}L^{*}=51.23, \\
a^{*}=2.54, \\
b^{*}=13.59\end{array}$ & $\begin{array}{l}L^{*}=41.48 \\
a^{*}=1.87 \\
b^{*}=10.98\end{array}$ \\
\hline
\end{tabular}

Figure 4: Photo images of the CO, CO-M, CO/S, CO$\mathrm{M} / \mathrm{S}, \mathrm{CO} / \mathrm{Ag}-\mathrm{S}$ and $\mathrm{CO}-\mathrm{M} / \mathrm{Ag}-\mathrm{S}$ samples was present (CO-M/S sample). The in situ synthesis of $\mathrm{Ag}$ Ps in the presence of the sumac leaf extract converted the yellow color of the cotton fibers into a brown color, caused by a decrease in the values of the $L^{*}$ and $b^{*}$ coordinates, as well as a change of the $a^{*}$ coordinate sign from negative to positive. The color change was more intense for the CO-M/Ag-S sample than for $\mathrm{CO} / \mathrm{Ag}-\mathrm{S}$ sample. These results clearly indicated that the presence of the sol-gel matrix increased the adsorption ability of the cotton fibers, for both the sumac leaf extract and $\mathrm{AgNO}_{3}$, and that the reduction of $\mathrm{Ag}^{+}$to $\mathrm{Ag}^{\circ}$ was accompanied by an intense color change. The latter was in accordance with the reports in the literature, in which the color change of the solution or of the textile substrates was chosen as the criteria for the formation of Ag Ps [25].

The antibacterial properties, presented in Figure 5, showed that not only Ag Ps (the CO-M/Ag-S sample), but also the sumac leaf extract (the CO-M/S sample) exhibited antibacterial activity. While the concentration of $\mathrm{Ag}$ on the cotton fibers was high enough to cause a $99-100 \%$ reduction of both $E$. coli and $S$. aureus bacteria, the phenolic compounds present in the water extract of the sumac leaves caused an excellent $99 \%$ growth reduction of $S$. aureus. On the other hand, the sumac leaf extract did not inhibit the growth of $E$. coli, but in contrast, it even promoted the bacterial growth which resulted in negative values of $R$. These findings were reasonable, since the substances in the sumac water and alcohol extracts are, in general, recognized as strong antibacterial agents against Gram-positive bacteria. The results also showed that the antibacterial activity of the CO-M/Ag-S sample was highly wash resistant, since a $100 \%$ bacterial reduction was obtained after five washings. This phenomenon was not observed

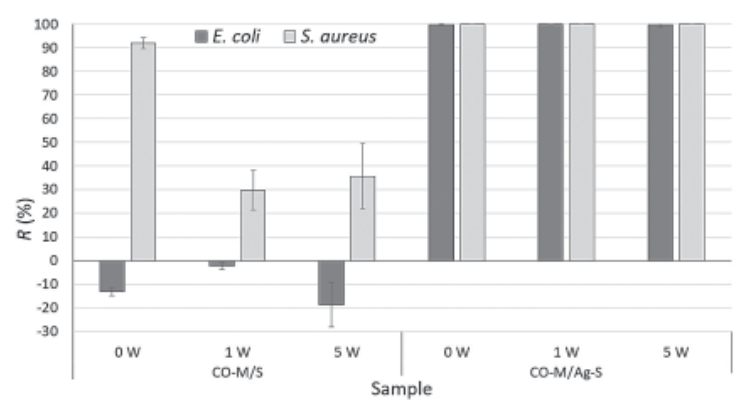

Figure 5: Reduction, $R$, of E. coli and S. aureus bacteria for the CO-M/S and CO-M/Ag-S samples, before $(0 \mathrm{~W})$ and after one $(1 \mathrm{~W})$ and five $(5 \mathrm{~W})$ consecutive washings 
for the CO-M/S sample, where the antibacterial substances were partially desorbed from the cotton fibers during the washing of the sample. A desorption of the sumac extract during repetitive washing resulted in a lightening of the color, which is expressed by the values of $\Delta E_{a b}^{\star}$ in Figure 6 . The lowest color change was determined for the CO-M/Ag-S sample, suggesting the durability of the chemical modification.

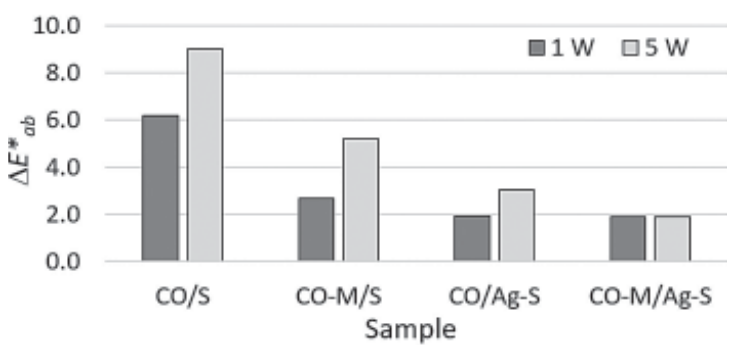

Figure 6: Color difference, $\Delta E_{a b}^{*}$, of the CO/S, CO$M / S, C O / A g-S$ and CO-M/Ag-S samples, unwashed and washed once $(1 W)$ and five $(5 W)$ times

The results in Figure 7 revealed that the presence of the sumac leaf extract (CO/S and CO-M/S samples) significantly decreased the transmission in the $280-400 \mathrm{~nm}$ spectral region in comparison to the $\mathrm{CO}$ and $\mathrm{CO}-\mathrm{M}$ samples. This was attributed to the UV absorbing action of the aromatic phenolic compounds included in the sumac leaf extract. In the visible light spectrum $(400-800 \mathrm{~nm})$, the transmission of $\mathrm{CO} / \mathrm{S}$ and $\mathrm{CO}-\mathrm{M} / \mathrm{S}$ samples gradually increased with increasing wavelength and almost reached the values of $37-40 \%$ in the 700-800 nm spectral region, which were characteristic for the $\mathrm{CO}$ and $\mathrm{CO}-\mathrm{M}$ samples, respectively, in the whole visible spectrum. These results confirmed that lower wavelengths of visible light were absorbed by the yellow pigments of the sumac leaf extract. In contrast, the transmission of the CO/Ag-S and CO-M/ Ag-S samples was very low in both UV and visible spectral region and it did not exceed $6 \%$ even at $800 \mathrm{~nm}$. This phenomenon implies that the brown colored Ag Ps successfully prevented the transmission in the whole measured spectral region.

The calculated UPF values summarized in Table 2 are in accordance with the results presented in Figure 7. Accordingly, the presence of the sumac leaf extract drastically increased the UPF, from 3.9 to 44.44, and this value was increased if the sol-gel matrix (the CO-M/S sample) and Ag Ps (the CO/Ag-S and $\mathrm{CO}-\mathrm{M} / \mathrm{Ag}-\mathrm{S}$ samples) were present on the cotton fibers. These results clearly indicate the excellent UV-protection properties of the sumac leaf extract. While the UPF of the CO/S, CO-M/S, CO/ Ag-S samples gradually decreased after subsequent washings (Figure 8) due to the sumac leaf extract desorption, the UPF of CO-M/Ag-S sample remained unchanged even after 5 washings, with a value of 66.5. This suggests that the interactions between the substances of the sumac leaf extract and Ag Ps, embedded in the sol-gel matrix, were strong

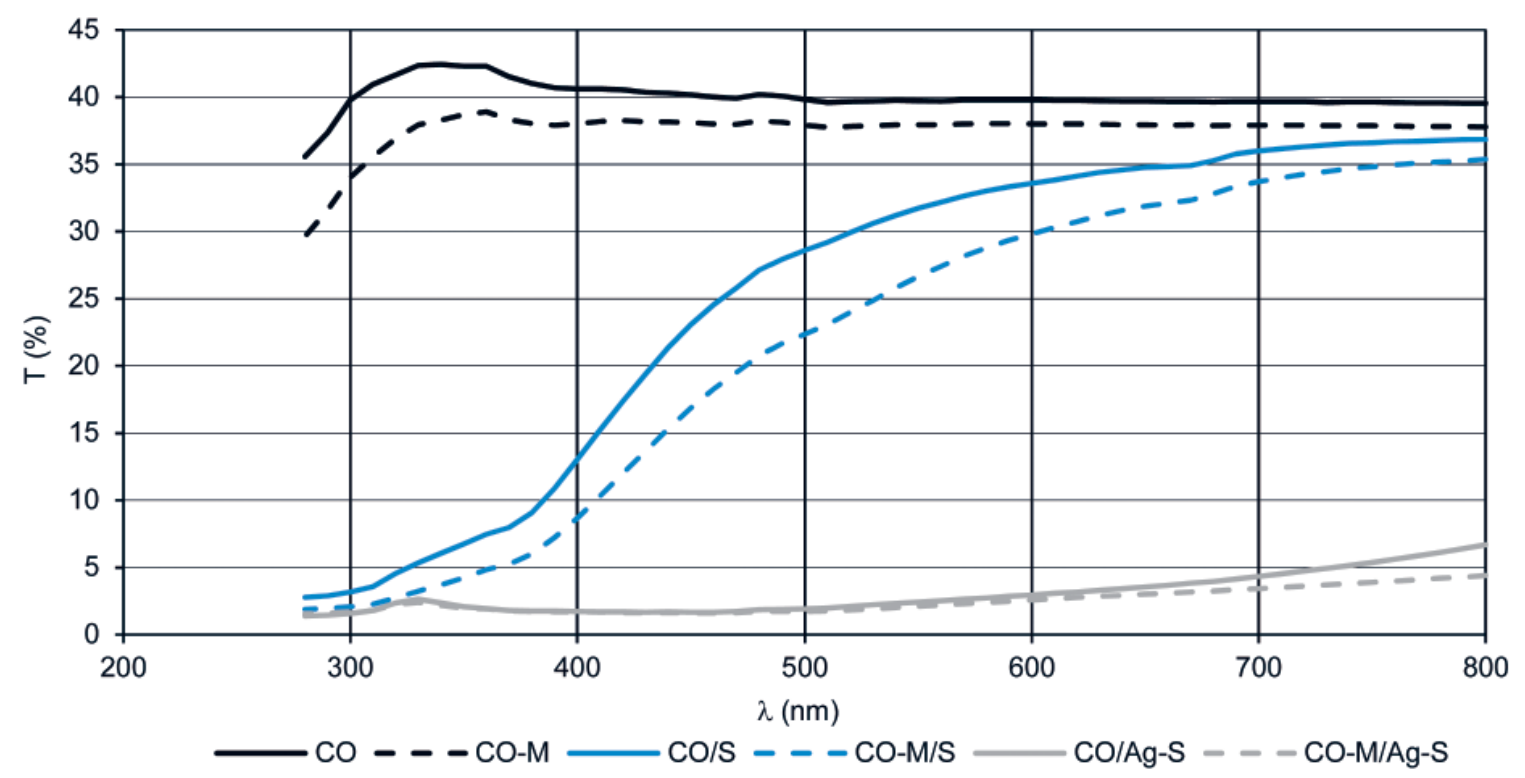

Figure 7: Transmission, T, versus wavelength, $\lambda$, for the CO, CO-M, CO/Ag-S and CO-M/Ag-S samples 
Table 2: Mean ultraviolet protection factor, UPF, UPF rating and UVR protection categories for the untreated and differently coated samples

\begin{tabular}{|l|c|c|c|c|c|c|c|c|}
\hline $\begin{array}{c}\text { Sample } \\
\text { code }\end{array}$ & $\begin{array}{c}\text { Mean } \\
\text { UPF }\end{array}$ & $\begin{array}{c}\text { T(UVA) } \\
(\%)\end{array}$ & $\begin{array}{c}\text { T(UVB) } \\
(\%)\end{array}$ & $\begin{array}{c}\text { T(UVR) } \\
(\%)\end{array}$ & $\begin{array}{c}\text { UVA } \\
\text { blocking } \\
(\%)\end{array}$ & $\begin{array}{c}\text { UVB } \\
\text { blocking } \\
(\%)\end{array}$ & $\begin{array}{c}\text { UPF } \\
\text { Rating }\end{array}$ & $\begin{array}{c}\text { UVR } \\
\text { protection } \\
\text { categorya) }\end{array}$ \\
\hline $\mathrm{CO}$ & 3.90 & 29.06 & 24.78 & 27.75 & 70.62 & 75.12 & 4 & $\mathrm{~N}$ \\
\hline $\mathrm{CO}-\mathrm{M}$ & 4.63 & 26.61 & 20.14 & 24.40 & 73.39 & 79.65 & 5 & $\mathrm{~N}$ \\
\hline $\mathrm{CO} / \mathrm{S}$ & 44.44 & 5.10 & 1.79 & 4.12 & 94.89 & 98.18 & 40 & $\mathrm{E}$ \\
\hline $\mathrm{CO}-\mathrm{M} / \mathrm{S}$ & 50.91 & 4.24 & 1.66 & 3.63 & 95.82 & 98.35 & 50 & $\mathrm{E}$ \\
\hline $\mathrm{CO} / \mathrm{Ag}-\mathrm{S}$ & 66.1 & 2.06 & 1.35 & 1.73 & 97.96 & 98.69 & 70 & $\mathrm{E}$ \\
\hline $\mathrm{CO}-\mathrm{M} / \mathrm{Ag}-\mathrm{S}$ & 66.46 & 1.63 & 1.30 & 1.48 & 98.42 & 98.76 & 70 & $\mathrm{E}$ \\
\hline
\end{tabular}

a) $\mathrm{N}$ - non-rateable; $\mathrm{E}$ - excellent

enough to provide a durable coating. However, to be able to discuss this phenomenon in more detail, some additional investigations of the chemical compositions of the coating should be carried out.

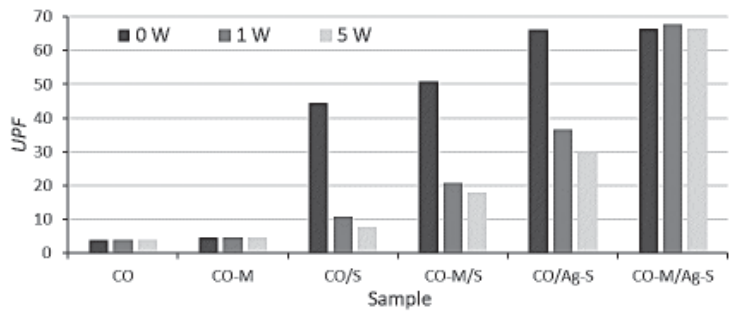

Figure 8: Ultraviolet protection factor, UPF, of the $\mathrm{CO}, \mathrm{CO}-\mathrm{M}, \mathrm{CO} / \mathrm{S}, \mathrm{CO}-\mathrm{M} / \mathrm{S}, \mathrm{CO} / \mathrm{Ag}-\mathrm{S}$ and CO-M/ Ag-S samples before $(0 \mathrm{~W})$ and after one $(1 \mathrm{~W})$ and five $(5 W)$ repetitive washings

\section{Conclusion}

In this research, we successfully created a highly durable antimicrobial and UV-protective coating on cellulose fibers by an in situ synthesis of Ag Ps in the presence of an extract of sumac leaves, which was used as a reducing agent. The results showed that:

- the sumac leaf extract colored the cellulose fibers in yellow, and the conversion of $\mathrm{Ag}$ cations to $\mathrm{Ag}$ Ps in the presence of the sumac leaf extract caused the fiber to be colored in brown;

- the concentration of $\mathrm{Ag}$ on the cotton fibers was high enough to cause a $99-100 \%$ reduction of both E. coli and S. aureus bacteria;

- the sumac leaf extract exhibited excellent antibacterial activity against $S$. aureus but did not inhibit the growth of E. coli;
- the sumac leaf extract provided high UV-protection, with a $U P F$ value equal to 44.44 , which was increased to 66.7, if Ag Ps were present on the cellulose fibers;

- the presence of the sol-gel matrix increased the adhesion ability of the cellulose fibers for the sumac leaf extract and Ag cations, resulting in an increased antibacterial activity and UV-protection properties of the chemically modified fibers, as well as their washing fastness.

\section{Acknowledgements}

This research was carried out in the framework of the courses Advanced Finishing Processes and Chemical Functionalization of Textiles in the Master Study Programme, Textile and Clothing Planning. The research was cofounded by the EU project UIA02-228 APPLAUSE (Alien Plant Species from harmful to useful with citizens' led activities) and the Slovenian Research Agency (Program P2-0213, Infrastructural Centre RIC UL-NTF). The authors would like to thank Assoc Prof Dr. Raša Urbas for her help at the $U V$-Vis measurements.

\section{References}

1. BEER, Christiane, FOLDBJERG, Rasmus, HAYASHI, Yuya, SUTHERLAND, Duncan S., AUTRUP, Herman. Toxicity of silver nanoparticles nanoparticle or silver ion? Toxicology Letters, 2012, 208(3), 286-292, doi: 10.1016/j.toxlet.2011. 11.002.

2. LIAO, Chengzhu, LI, Yuchao, TJONG, Sie Chin. Bactericidal and cytotoxic properties of silver 
nanoparticles. International Journal of Molecular Sciences, 2019, 20(2), 1-47, doi: 10.3390/ ijms20020449.

3. ELSHAARAWY, Reda F. M., SEIF, Gelan A., ELNAGGAR, Mehrez E., MOSTAFA, Tahia B., ELSAWI, Emtithal A. In-situ and ex-situ synthesis of poly-(imidazolium vanillyl)-grafted chitosan/ silver nanobiocomposites for safe antibacterial finishing of cotton fabrics. European Polymer Journal, 2019, 116, 210-221, doi: 10.1016/j. eurpolymj.2019.04.013.

4.CALHAN, Ebru, MAHLTIG, Boris. Microwaveassisted process for silver/silica sol application onto cotton fabrics. Journal of Sol-Gel Science and Technology, 2019, 92(3), 607-617, doi: 10. 1007/s10971-019-05149-2.

5. MAHLTIG, Boris, FIEDLER, D., SIMON, P. Silver-containing sol-gel coatings on textiles: antimicrobial effect as a function of curing treatment. Journal of the Textile Institute, 2011, 102(9), 739-745, doi: 10.1080/00405000.2010. 515730 .

6. RAJAN, Ramachandran, CHANDRAN, Krishnaraj, HARPER, Stacey L., YUN, Soon-Il, KALAICHELVAN, P. Thangavel. Plant extract synthesized silver nanoparticles: an ongoing source of novel biocompatible materials. Industrial Crops and Products, 2015, 70, 356-373, doi: 10.1016/j.indcrop.2015.03.015.

7. ANSHU, Singh, SUJATA, Shekhar, SHRIVASTAVA, J. N. Biosynthesis of silver nanoparticles from various microbial and green resources: a review. Research Journal of Biotechnology, 2019, 14(8), 120-130.

8. SHAHEEN, Th. I., ABD EL ATY, Abeer A. Insitu green myco-synthesis of silver nanoparticles onto cotton fabrics for broad spectrum antimicrobial activity. International Journal of Biological Macromolecules, 2018, 118(Part B), 2121-2130, doi: 10.1016/j.ijbiomac.2018.07.062.

9. VANTI, Gulamnabi L., NARGUND, Vijendra B., BASAVESHA, K. N., VANARCHI, Rajinikanth, KURJOGI, Mahantesh, MULLA, Sikandar I., TUBAKI, Suresh, PATIL, Rajashekar R. Synthesis of Gossypium hirsutum-derived silver nanoparticles and their antibacterial efficacy against plant pathogens. Applied Organometallic Chemistry, 2019, 33(1), 1-9, doi: 10.1002/aoc.4630.

10. RAO, Amara Venkateswara, ASHOK, Basa, MAHESH, Mallavarapu Uma, SUBBAREDDY,
Gopireddy Venkata, SEKHAR, Vatti Chandra, RAMANAMURTHY, Gollapudi Venkata, RAJULU, Anumakonda Varada. Antibacterial cotton fabrics with in situ generated silver and copper bimetallic nanoparticles using red sanders powder extract as reducing agent. International Journal of Polymer Analysis and Characterization, 2019, 24(4), 346-354, doi: 10.1080/1023666X. 2019.1598631.

11. KARAMIAN, Roya, KAMALNEJAD, Jamalaldin. Green synthesis of silver nanoparticles using Cuminum cyminum leaf extract and evaluation of their biological activities. Journal of Nanostructures, 2019, 9(1), 74-85, doi: 10.22052/ JNS.2019.01.008.

12. UL-ISLAM, Shahid, BUTOLA, B. S., VERMA, Deepali. Facile synthesis of chitosan-silver nanoparticles onto linen for antibacterial activity and free-radical scavenging textiles. International Journal of Biological Macromolecules, 2019, 133, 1134-1141, doi: 10.1016/j.ijbiomac.2019.04.186.

13. UL-ISLAM, Shahid, BUTOLA, B. S., GUPTA, Abhishek, ROY, Anasuya. Multifunctional finishing of cellulosic fabric via facile, rapid in-situ green synthesis of AgNPs using pomegranate peel extract biomolecules. Sustainable Chemistry and Pharmacy, 2019, 12, 1-8, doi: 10.1016/j. scp.2019.100135.

14. ABOUTORABI, S. Najmeh, NASIRIBOROUMAND, Majid, MOHAMMADI, Pourya, SHEIBANI, Hassan, BARANI, Hossein. Biosynthesis of silver nanoparticles using Safflower flower: structural characterization, and its antibacterial activity on applied wool fabric. Journal of Inorganic and Organometallic Polymers and Materials, 2018, 28(6), 2525-2532, doi: 10.1007/ s10904-018-0925-5.

15. SHAHRIARY, Marjan, VEISI, Hojat, HEKMATI, Malak, HEMMATI, Saba. In situ green synthesis of Ag nanoparticles on herbal tea extract (Stachys lavandulifolia)-modified magnetic iron oxide nanoparticles as antibacterial agent and their 4-nitrophenol catalytic reduction activity. Materials Science \& Engineering: C - Materials for Biological Applications, 2018, 90, 57-66, doi: 10.1016/j.msec.2018.04.044.

16. SARAVANAKUMAR, Arthanari, PENG, Mei Mei, GANESH, Mani, JAYAPRAKASH, Jayabalan, MOHANKUMAR, Murugan, JANG, Hyun Tae. Low-cost and eco-friendly green synthesis 
of silver nanoparticles using Prunus japonica (Rosaceae) leaf extract and their antibacterial, antioxidant properties. Artificial Cells Nanomedicine and Biotechnology, 2017, 45(6), 11651171, doi: 10.1080/21691401.2016.1203795.

17. ZHOU, Qingqing, LV, Jingchun, REN, Yu, CHEN, Jiayi, GAO, Dawei, LU, Zhenqian, WANG, Chunxia. A green in situ synthesis of silver nanoparticles on cotton fabrics using Aloe vera leaf extraction for durable ultraviolet protection and antibacterial activity. Textile Research Journal, 2017, 87(19), 2407-2419, doi: 10.1177/0040517516671124.

18. RAYNE, Sierra, MAZZA, G. Biological activities of extracts from sumac (Rhus spp.): a review. Plant Foods for Human Nutrition, 2007, 62(4), 165-175, doi: 10.1007/s11130-007-0058-4.

19. WANG, Sunan, ZHU, Fan. Chemical composition and biological activity of staghorn sumac (Rhus typhina). Food Chemistry, 2017, 237, 431443, doi: 10.1016/j.foodchem.2017.05.111.

20. ASTM E2149-01. Standard Test Method for Determining the Antimicrobial Activity of Immobilized Antimicrobial Agents Under Dynamic Contact Conditions (Withdrawn 2010). West Conshohocken: ASTM International, 2001, 1-4.

21. LEE, Seungsin. Developing UV-protective textiles based on electrospun zinc oxide nanocom- in situ Synthesis of Silver Particles in the Presence of a Sol-gel

Matrix and Sumac Leaf Extract

posite fibers. Fibers and Polymers, 2009, 10, 295-301, doi: 10.1007/s12221-009-0295-2.

22. AS/NZS 4399:2017 Sun Protective Clothing Evaluation and Classification. Sydney, Wellington: Standards Australia, Standards New Zealand, 2017, 1-8.

23. BERGER-SCHUNN, Anni. Practical color measurement. New York : John Wiley \& Sons, 1994.

24. ROMEO, Flora V., BALLISTRERI, Gabriele, FABRONI, Simona, PANGALLO, Sonia, NICOSIA, Maria Giulia Li Destri, SCHENA, Leonardo, RAPISARDA, Paolo. Chemical characterization of different sumac and pomegranate extracts effective against Botrytis cinerea Rots. Molecules, 2015, 20(7), 11941-11958, doi: 10. 3390/molecules200711941.

25. MORALES-LUCKIE, Raul A., LOPEZFUENTES-RUIZ Adrian, Aldo, OLEA-MEJIA, Oscar F., LILIANA, Argueta-Figueroa, SANCHEZMENDIETA, Victor, BROSTOW, Witold, HINESTROZA, Juan P. Synthesis of silver nanoparticles using aqueous extracts of Heterotheca inuloides as reducing agent and natural fibers as templates: Agave lechuguilla and silk. Materials Science \& Engineering: $C$ - Materials for Biological Applications, 2016, 69, 429-436, doi: 10. 1016/j.msec.2016.06.066. 